\title{
ANALISA PERENCANAAN PERLUASAN COVERAGE AREA LTE DI KABUPATEN GARUT
}

\author{
Ryan Rasyid Yusuf ${ }^{1}$, Uke Kurniawan Usman², Yuyun Siti Rohmah ${ }^{3}$ \\ 1, 2, ${ }^{3}$ Fakultas Teknik Elektro, Universitas Telkom \\ 1, 2, ${ }^{3}$ Fakultas Teknik Elektro, Universitas Telkom \\ ${ }^{1}$ ryanrasyidy@student.telkomuniversity.ac.id,2ukeusman@telkomuniversity.ac.id, \\ 3 yuyunsitirohmah@telkomuniversity.ac.id
}

\begin{abstract}
Abstrak
Daerah kabupaten Garut merupakan tujuan wisata yang ramai dikunjungi wisatawan di Jawa Barat. Di daerah ini terdapat beberapa tempat wisata unggulan seperti Taman Satwa Cikembulan, Puncak Darajat, dan Pemandian Cipanas yang setiap harinya didatangi ribuan wisatawan. Kebutuhan akan layanan komunikasi suara dan data sangat dibutuhkan di daerah ini. Kondisi jaringan LTE di daerah kabupaten Garut belum sepenuhnya merata. Berdasarkan hasil survey, diperoleh permasalahan blank spot (RSRP $>-\mathbf{- 1 0 0} \mathrm{dBm}$ ), kualitas sinyal yang kurang baik (SINR >-20 dB), dan throughput yang lambat pada beberapa kecamatan. Untuk mengatasi masalah ini, perlu dilakukan perencanaan perluasan jaringan LTE di beberapa kecamatan tersebut. Perencanaan perluasan yang dilakukan menggunakan dua skenario, yaitu LTE (FDD) di $1800 \mathrm{MHz}$ dan LTE-A menggunakan metode carrier aggregation di $850 \mathrm{MHz}$ dan $1800 \mathrm{MHz}$ yang dikombinasikan dengan SFR. Pada penelitian ini, setelah dilakukan perencanaan perluasan didapatkan peningkatan luasan coverage area sebesar 331,76 km2 $(92,29142 \%)$ dengan kualitas yang memenuhi standar KPI. Hasil simulasi perencanaan perluasan coverage area menggunakan LTE (FDD) didapatkan jumlah site sebanyak 88, nilai parameter RSRP rata-rata $-65,91 \mathrm{dBm}$, SINR rata-rata $18,02 \mathrm{~dB}$, throughput 24,962 Mbps, dan user connected 93,3 \%. Sedangkan hasil simulasi perluasan coverage area menggunakan LTE-A (Carrier Aggregation) yang dikombinasikan dengan SFR didapatkan jumlah site sebanyak 69, nilai parameter RSRP rata-rata $-48,88 \mathrm{dBm}$, SINR rata-rata $22,5 \mathrm{~dB}$, throughput $28,923 \mathrm{Mbps}$, dan user connected $94,5 \%$.
\end{abstract}

Kata Kunci: LTE, LTE-A, Carrier Aggregation, SFR, RSRP, SINR, user connected, Throughput.

\section{Abstract}

Garut district is a tourist destination visited by tourists in West Java. In this area there are some excellent tourist attractions such as Cikembulan Animal Park, Puncak Darajat and Cipanas, that every day in the coming thousands of tourists. The need for voice and data communications services is needed in this area. The condition of the LTE network in Garut district area is not fully uniform. Based on survey results, blank spot problems $($ RSRP $>-100 \mathrm{dBm}$ ), poor signal quality (SINR $>-20 \mathrm{~dB}$ ), and low throughput in some sub-districts were founded. To overcome this problems, LTE network expansion planning needs to be done in some sub-districts. Expansion planning is carried out using two scenarios, LTE (FDD) at $1800 \mathrm{MHz}$ and LTE-A using carrier aggregation methods at $850 \mathrm{MHz}$ and $1800 \mathrm{MHz}$ combined with SFR. In this paper, after the expansion plan is obtained an increase in coverage area of $331.76 \mathrm{~km}^{2}(\mathbf{9 2 . 2 9 1 4 2 \%})$ with quality that meets the standards of KPI. The result of simulation planning of expansion of coverage area using LTE (FDD) got 88 site amount, RSRP parameter value average $-\mathbf{- 6 5 . 9 1} \mathrm{dBm}$, SINR average $18.02 \mathrm{~dB}$, throughput $24.962 \mathrm{Mbps}$, and user connected 93.3\%. While the result of simulation of expansion of coverage area using LTE-A (Carrier Aggregation) combined with SFR obtained the number of sites as much as 69, RSRP parameter value average $-48.88 \mathrm{dBm}$, SINR average $22.5 \mathrm{~dB}$, throughput 28.923 Mbps, and user connected 94.5\%.

Key Words: LTE, LTE-A, Carrier Aggregation, SFR, RSRP, SINR, User Connected, Throughput.

1. Pendahuluan

Di Indonesia, jaringan 4G LTE belum sepenuhnya merata kesetiap daerah. Saat ini hanya kota-kota besar yang sudah ter-cover layanan ini seperti Jakarta, Bandung, Bogor, Tasikmalaya, Sukabumi, dsb [1]. Padahal, masih terdapat lokasi-lokasi potensial market 
yang lebih membutuhkan layanan jaringan $4 \mathrm{G}$ ini salah satunya adalah daerah kabupaten Garut. Kabupaten Garut merupakan tujuan wisata yang ramai dikunjungi wisatawan di Jawa Barat. Di lokasi ini terdapat beberapa tempat wisata unggulan seperti Taman Satwa Cikembulan, Puncak Darajat, Pemandian Cipanas, dan masih banyak lainnya. Kondisi jaringan LTE di daerah kabupaten Garut saat ini hanya terdapat di pusat kota dengan coverage yang kecil dan performansi yang belum optimal. Berdasarkan hasil survey, diperoleh permasalahan blank spot (RSRP $>-100 \mathrm{dBm})$, kualitas sinyal yang kurang baik (SINR $>-20 \mathrm{~dB}$ ), dan throughput data yang lambat. Untuk mengatasi permasalahan ini, maka dilakukan perencanaan perluasan jaringan LTE menggunakan metodecarrier aggregation di frekuensi $850 \mathrm{MHz}$ dan $1800 \mathrm{MHz}$ dengan daerah studi kasus kabupaten Garut. Kemudian untuk mendapatkan performansi yang maksimal, perancanaan perluasaan jaringan ini dilakukan menggunakan dua skenario yaitu pada frekuensi 1800 MHz/ LTE (FDD) dan frekuensi 1800-850 MHz/ LTE-A (Carrier Aggregation) yang dikombinasikan dengan Soft Frequency Reuse (SFR).

\section{Dasar Teori}

\subsection{Long Term Evolution (LTE)}

Long Term Evolution (LTE) adalah nama yang diberikan untuk standar teknologi komunikasi baru yang dikembangkan oleh 3GPP untuk mengatasi permintaan kebutuhan akan layanan komunikasi yang semakin meningkat, LTE adalah lanjutan dari evolusi $2 \mathrm{G}$ dan $3 \mathrm{G}$ yang bertujuan untuk menyediakan layanan dengan tingkat kualitas yang sama dengan jaringan wired. LTE memiliki kemampuan kecepatan transfer data maksimum mencapai 100 Mbps pada sisi downlink dan 50 Mbps pada sisi uplink dengan bandwidth $20 \mathrm{Mhz}$. Selain itu LTE mampu medukung semua aplikasi yang ada baik, voice, data, video, maupun IP-TV [2].

\subsection{Long Term Evolution-Advanced (LTE-A)}

LTE-Advanced merupakan istilah yang digunakan untuk versi LTE yang membahas persyaratan lanjutan IMT, seperti yang ditentukan pada 3GPP Release 10 dan seterusnya. LTE-Advanced merupakan pengembangan lanjutan dari teknologi LTE yang memungkinkan jaringan memiliki pencapaian coverage area yang lebih besar, lebih stabil, dan lebih cepat. Biasanya pengembangan ini dicapai dengan penggunaan teknik multi antena (MIMO), penggunaan carrier aggregation, dan penambahan relay nodes [3].

\subsection{Carrier Aggregation}

Untuk mencapai peak data rate yang disyaratkan oleh IMT-Advanced, 3GPP LTE Rilis 10 telah memperkenalkan carrier aggregation (CA). CA adalah teknologi yang memungkinkan jaringan $4 \mathrm{G}$ berjalan di dua frekuensi berbeda serta dapat menggabungkan beberapa Component Carriers (CC) agar tercapai peak data rate. CC dapat memiliki bandwidth 1,4, 3, 5, 10, 15 atau $20 \mathrm{MHz}$ dan maksimal lima CC dapat digabungkan, maka bandwidth maksimum adalah $100 \mathrm{MHz}$ [4].

\subsection{Perencanaan Berdasarkan Kapasitas}

Perencanaan berdasarkan kapasitas dilakukan untuk melakukan perencanaan yang mengutamakan terpenuhinya kebutuhan trafik pengguna. Data estimasi jumlah pelanggan dibeberapa kecamatan di daerah Garut didapatkan dari Badan Pusat Statistika untuk daerah kabupaten Garut.

Terdapat persamaan yang digunakan untuk melakukan perencanaan perluasan berdasarkan kapasitas yaitu:

$$
\begin{aligned}
& \frac{T}{S}=S T \times S D R \times B R \times\left[\frac{1}{(1-B L E R)}\right] \\
& S U T=\frac{\sigma\left(\frac{T}{S} \times B H S A \times P \times(1+P A P R)\right)}{3600} \\
& N T(P)=S U T \times \text { Total Target User } \\
& N T(M A C)=\frac{U L N T}{0,98} \\
& D L C R+C R C=(168-36-12) \times C B \times C R \\
& \times N \times C \times 1000 \\
& D L C R+C R C=(168-36-12) \times C B \times C R \\
& \times N \times C \times 1000 \\
& U L C C+C R C=(168-24) \times C B \times C R \\
& \times N \times C \times 1000 \\
& \frac{\text { Capacity }}{\text { site }}=3 \times \text { Cell Average Troughput } \\
& \text { Number Site }=\frac{N T}{\sqrt{\frac{\text { Capacity }}{\text { Site }}}} \\
& \text { Cell } 3 \text { Sector }=\sqrt{\frac{\text { Cell Coverage }}{2,6 \times 1,95}}
\end{aligned}
$$

$$
\begin{array}{ll}
\text { Keterangan: } & \\
\text { T/S } & =\text { Throughput/ Session }(\mathrm{kbit}) \\
\text { SDR } & =\text { Session Duty Ratio } \\
\text { BR } & =\text { Bearer Rate }(\mathrm{kbps}) \\
\text { DLCC } & =\text { Downlink Cell Capacity }(\mathrm{kbps}) \\
\text { ULCC } & =\text { Uplink Cell Capacity }(\mathrm{kbps}) \\
\text { SUT } & =\text { Single User Throughput }(\mathrm{kbps}) \\
\text { N } & =\text { Number of Resource Block } \\
\text { C } & =\text { Transmitter } \\
\text { PAPR } & =\text { Peak Average Power Ratio }(\%) \\
\text { NT(IP) } & =\text { Network Throughput }(\mathrm{kbps}) \\
\text { NT(MAC) } & =\text { Network Throuhgput MAC Layer }(\mathrm{kbps})
\end{array}
$$




\subsection{Perencanaan Berdasarkan Coverage}

Perencanaan berdasarkan coverage merupakan metode perencanaan jaringan seluler untuk memastikan jaringan dapat memberikan layanan/signal pada seluruh daerah tinjauan.

Terdapat beberapa persamaan yang digunakan untuk melakukan perencanaan perluasan berdasarkan coverage yaitu:

$$
\begin{aligned}
M A P L & =(E I R P / S c)-M S R-P L-S F M \\
\frac{E I R P}{S c} & =P S c+T \times A G-T \times C L-B L \\
M S R & =S R_{x}-R_{x} A G+R_{x} C L+R_{x} B L+M \\
P S c & =P T_{x}-10 \log (N S c) \\
S R x & =\left(\frac{T N}{S c}\right)+N F e N o d e B+S I N R \\
\frac{T N}{S c} & =10 \log \left(K_{x} T_{x} W\right) \\
\sigma L T E & =\frac{\text { Total Wide Area }}{\text { Wide of Cell }}
\end{aligned}
$$

Keterangan:

$$
\begin{array}{ll}
\text { MAPL } & =\text { Maximum Allowable Pathloss }(\mathrm{dB}) \\
\text { EIRP } & =\text { Effective Isotropic Radiated Power }(\mathrm{dBm}) \\
\text { PTx } & =\text { Power Transmitter }(\mathrm{dBm}) \\
\mathrm{PSc} & =\text { Power of Subcarrier } \\
\mathrm{Tx} & =\text { Transmitter } \\
\mathrm{Rx} & =\text { Receiver } \\
\mathrm{Sc} & =\text { Subcarrier } \\
\mathrm{NSc} & =\text { Number of subcarrier } \\
\mathrm{MSR} & =\text { Minimum Signal Strength }(\mathrm{dBm}) \\
\mathrm{PL} & =\text { Penetration Loss }(\mathrm{dB}) \\
\mathrm{AG} & =\text { Antenna Gain }(\mathrm{dBi}) \\
\mathrm{CL} & =\text { Cable Loss }(\mathrm{dB}) \\
\mathrm{BL} & =\text { Body Loss }(\mathrm{dB}) \\
\mathrm{TN} & =\text { Thermal Noise }(\mathrm{dB}) \\
\mathrm{NF} & =\text { Noise Figure }(\mathrm{dB}) \\
\mathrm{K} & =\text { Boltzman Constant } \\
\mathrm{T} & =\text { Temperature }(\mathrm{K}) \\
\mathrm{W} & =\text { Bandwidth }(\mathrm{Hz})
\end{array}
$$

\subsection{Model Propagasi}

Model propagasi digunakan untuk menghitung jari-jari sel $(d)$. Model propagasi yang digunakan dalam penelitian ini yaitu Cost-231 dan Okumura Hatta. Adapun persamaannya adalah sebagai berikut.

Persamaan Okumura Hatta:

$$
\begin{aligned}
& \begin{aligned}
L u & =69,55+26,16 \log f-13,82 \log h b-C h \\
& +[44.9-6.55 \log h b] \log d
\end{aligned} \\
& C h=(1,1 \log f-0,7) h r-(1,56 \log f-0,8)
\end{aligned}
$$

Tabel 1. Target KPI untuk Tiap Parameter

\begin{tabular}{|c|c|l|}
\hline Objective & Parameter & Target KPI \\
\hline Accessbility & User Connected & $\geq 90 \%$ \\
\hline Coverage & RSRP & $\begin{array}{l}90 \% \geq-100 \\
\mathrm{dBm}\end{array}$ \\
\hline Kualitas Sinyal & SINR & $90 \% \geq 5 \mathrm{~dB}$ \\
\hline Service Integrity & Throughput & $\geq 12 \mathrm{Mbps}$ \\
\hline
\end{tabular}

Persamaan Cost-231:

$$
\begin{gathered}
a(h m)=(1,1 \log f-0,7) h r-(1,56 \log f-0,8) \\
P L=46,3+33,9(\log f)-13,82 \log h b- \\
a(h m)+(44,9-6,55 \log h b) \log d+C m
\end{gathered}
$$

\subsection{Soft Frequency Reuse (SFR)}

Soft Frequency Reuse adalah skema frekuensi reuse dimana area cakupan dibagi menjadi dua area yaitu cell centre dan cell edge. Cell centre adalah area cakupan dengan jari-jari sel dengan menggunakan subband bandwidth dengan menggunakan daya pancar. Cell edge adalah area cakupan sel dengan jari-jari sel dengan menggunakan skema frekuensi reuse lebih besar dari satu dan menggunakan daya pancar cell centre [5] [6].

\subsection{Key Performance Indicator (KPI)}

Key Performance Indicator (KPI) berisi parameter-parameter yang merupakan indikator untuk menentukan performansi suatu jaringan. Pada masing-masing parameter tersebut mempunyai target KPI yang harus dicapai untuk memenuhi kualitas jaringan.

\section{Tahap Perencanaan Perluasan}

\subsection{Alur Perencanaan Perluasan Coverage Area LTE}

\subsection{Pengukuran Kondisi Jaringan LTE Awal}

Berdasarkan Gambar 2 dapat dilihat bahwa jaringan LTE belum sepenuhnya terdistribusi secara merata ke setiap kecamatan. Daerah yang telah terdapat jaringan LTE berada di kecamatan Garut kota. Adapun nilai RSRP di beberapa kecamatan selain Garut Kota yaitu berada pada kisaran - $102 \mathrm{dBm}$ sampai $-150 \mathrm{dBm}$ dengan nilai SINR berkisar 0 sampai $-20 \mathrm{~dB}$. Hal ini membuktikan bahwa di kecamatan tersebut belum terdapat jaringan LTE (blank spot).

\subsection{Skenario Perencanaan Perluasan}

Pada penelitian ini, perencanaan perluasan jaringan LTE menggunakan 2 skenario yaitu LTE (FDD) dan LTE-A (Carrier Aggregation) yang dikombinasikan dengan SFR. Pada skenario perencanaan perluasan coverage area dengan LTE (FDD) digunakan frekuensi $1800 \mathrm{MHz}$, sedangkan pada perencanaan perluasan 


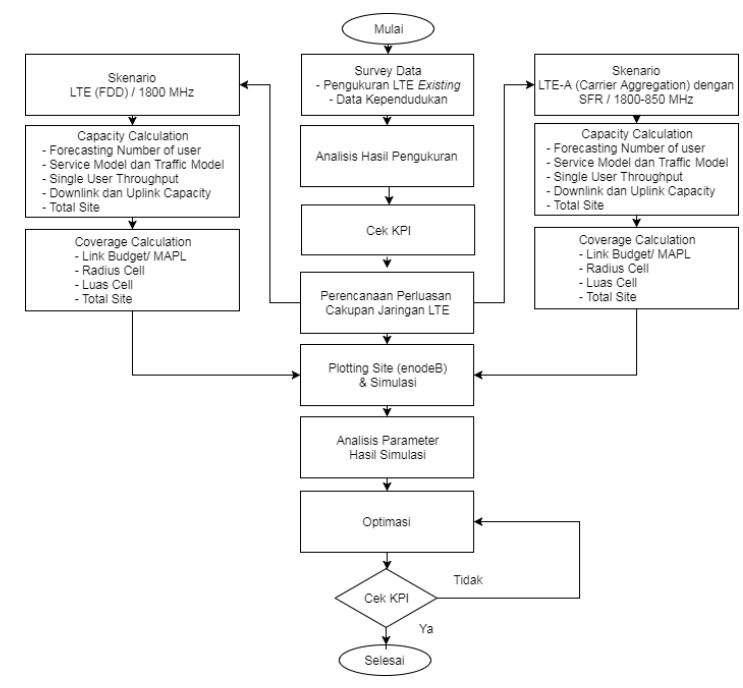

Gambar 1. Diagram Alir Pengerjaan Perencanaan Perluasan Coverage LTE

coverage area LTE-A (Carrier Aggregation) menggunakan frekuensi $1800-850 \mathrm{MHz}$ dengan bandwidth total $15 \mathrm{MHz}$.

\subsection{Perencanaan Perluasan Berdasarkan kapasitas \\ 3.4.1 Forecasting Jumlah Pelanggan \\ - Jumlah populasi tahun $2022=551.565$ orang \\ - Usia Produktif 65\% = 357.106 orang \\ - Operator market share $40 \%=142.842$ orang \\ - Penetrasi LTE 25\% = 35.711 orang \\ - Penetrasi LTE-A 25\% $=16.070$ orang}

\subsubsection{Service Model dan Traffic Model}

Service model adalah acuan jumlah minimal throughput agar pelanggan dapat mengakses layanan. Traffic model adalah model trafik yang dijadikan acuan untuk menghitung single user throughput untuk setiap layanan. Beberapa kecamatan yang akan dilakukan perluasan tergolong kedalam bentuk morfologi sub urban.

\subsubsection{Single User Throughput}

Single user throughput adalah jumlah minimal throughput yang harus dimiliki setiap pelanggan untuk mengakses semua layanan.

\subsubsection{Network Throughput}

Network throughput adalah jumlah throughput yang dibutuhkan untuk keseluruhan jumlah pengguna yang direncanakan dalam mengakses semua layanan. Network throughput diperoleh dengan mengalikan nilai single user throughput dengan 35.711 pengguna untuk jaringan LTE (FDD) dan 16.070 pengguna untuk jaringan LTE-A (Carrier Aggregation).

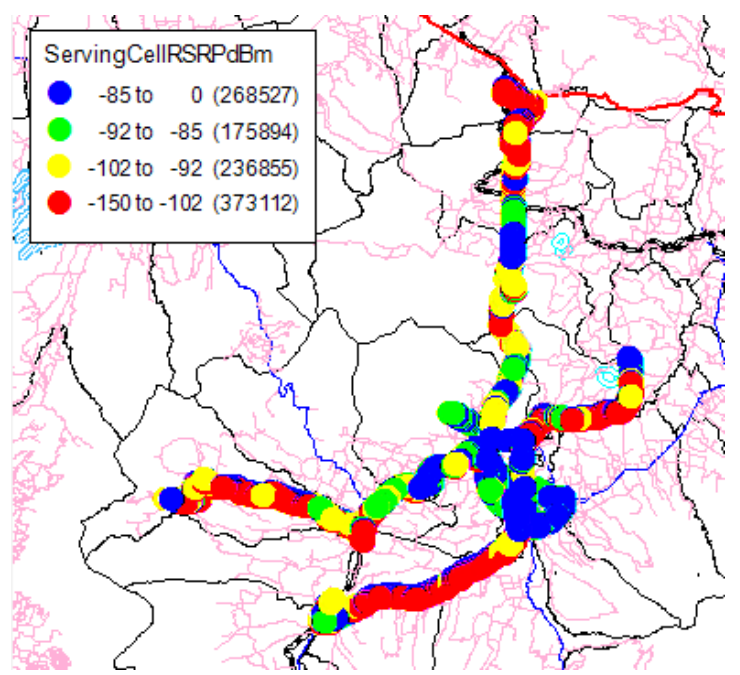

Gambar 2. Hasil drivetest parameter RSRP dan SINR

\subsubsection{Radio Overhead}

Radio Overhead berfungsi untuk mengkonversi throughput di layer IP ke layer MAC, setelah adanya penambahan header sebesar 0,98 disetiap penurunan layer.

\subsubsection{Distribusi Rata-rata SINR}

Tabel distribusi SINR digunakan untuk menghitung kapasitas sel dan kapasitas site dari sisi uplink maupun downlink. Berikut Tabel 6 menunjukan distribusi SINR dan kapasitas untuk frekuensi $1800 \mathrm{MHz}, 850 \mathrm{MHz}$, dan1800-850 MHz.

Berdasarkan Tabel 6 dapat diketahui kapasitas site throughput untuk frekuensi $1800 \mathrm{MHz}$ arah downlink sebesar 101,0879 Mbps dan arah uplink sebesar 60,6527 Mbps. Kapasitas site throughput arah downlink sebesar 73,5407 Mbps dan arah uplink sebesar 88,2489 Mbps. Kemudian, kapasitas site throughput arah downlink sebesar 261,5975 Mbps dan arah uplink sebesar 156,9585 Mbps.

\subsubsection{Perhitungan Jumlah Site}

Berdasarkan hasil perhitungan kapasitas maka didapatkan jumlah site seperti pada Tabel 9 berikut ini. Berdasarkan pada Tabel 9 didapatkan jumlah site untuk LTE (FDD) sebanyak 88 site, sedangkan untuk LTE-A (Carrier Aggregation) sebanyak 15 site. Jumlah site yang digunakan untuk dilakukan simulasi diambil, jumlah site yang paling banyak hal ini didasarkan untuk mendapatkan kualitas coverage yang lebih baik. 
Tabel 2. Service Model dan Traffic Model

\begin{tabular}{|c|c|c|c|c|}
\hline \multirow[t]{2}{*}{$\begin{array}{l}\text { Trafik } \\
\text { Parameter }\end{array}$} & Uplink & Downlink & $\begin{array}{l}\text { Sub } \\
\text { Urban }\end{array}$ & \multirow[b]{2}{*}{ BHSA } \\
\hline & $\begin{array}{l}\text { Throughput/ } \\
\text { Session } \\
\text { (kbps) }\end{array}$ & $\begin{array}{l}\text { Throughput/ } \\
\text { Session } \\
\text { (kbps) }\end{array}$ & $\begin{array}{l}\text { Traffic } \\
\text { Penetration }\end{array}$ & \\
\hline VoIP & 869,49 & 869,49 & $100 \%$ & 1,9 \\
\hline $\begin{array}{l}\text { Video } \\
\text { Phone }\end{array}$ & 4421,31 & 4421,31 & $35 \%$ & 0,45 \\
\hline $\begin{array}{l}\text { Video } \\
\text { Converence }\end{array}$ & 113690,91 & 113690,91 & $17 \%$ & 0,33 \\
\hline $\begin{array}{l}\text { Real Time } \\
\text { Gaming }\end{array}$ & 11367,27 & 90952,73 & $40 \%$ & 1,37 \\
\hline $\begin{array}{l}\text { Streaming } \\
\text { Media }\end{array}$ & 5683,64 & 864016,36 & $20 \%$ & 3,05 \\
\hline $\begin{array}{l}\text { IMS } \\
\text { Signalling }\end{array}$ & 22,10 & 22,10 & $40 \%$ & 4 \\
\hline $\begin{array}{l}\text { Web } \\
\text { Browsing }\end{array}$ & 5684,55 & 22737,27 & $100 \%$ & 3,5 \\
\hline $\begin{array}{l}\text { File } \\
\text { Transfer }\end{array}$ & 85272,73 & 454751,52 & $30 \%$ & 0,2 \\
\hline Email & 7106,06 & 37895,96 & $55 \%$ & 0,45 \\
\hline $\begin{array}{l}\text { P2P File } \\
\text { Sharing }\end{array}$ & 303151,52 & 909503,03 & $26 \%$ & 0,4 \\
\hline
\end{tabular}

Tabel 3. Service Model dan Traffic Model

\begin{tabular}{|c|c|c|}
\hline Traffic & Total & $\begin{array}{c}\text { Single User } \\
\text { Throughput (Kbps) }\end{array}$ \\
\hline UL & 84432,57 & 23,4535 \\
\hline DL & 883559,01 & 245,4331 \\
\hline
\end{tabular}

\subsection{Perencanaan Perluasan Berdasarkan Coverage.}

\subsubsection{Maximum Allowable Pathloss (MAPL)}

Maximum Allowable Pathloss (MAPL) adalah nilai maksimum loss yang diizinkan. MAPL dihitung di sisi uplink dan downlink, sehingga ketika pelanggan mengalami loss lebih kecil daripada nilai MAPL yang telah diperhitungkan, maka pelanggan masih dapat mengakses layanan.

Berdasarkan pada Tabel 10 maka didapatkan nilai MAPL yaitu sebesar 142,676 dB untuk frekuensi 1800 $\mathrm{MHz}$, dan 132,676 dB untuk frekuensi $850 \mathrm{MHz}$.

\subsubsection{Perhitungan Radius Cell}

Setelah mendapatkan nilai MAPL, selanjutnya adalah menentukan radius cell. Dalam proses perhitungan radius cell digunakan 2 buah model propagasi yaitu Cost-231 untuk frekuensi $1800 \mathrm{MHz}$ dan Okumura Hatta untuk frekuensi $850 \mathrm{MHz}$.

\subsubsection{Perhitungan Jumlah Site}

Setelah diperoleh nilai cell radius untuk setiap frekuensi maka selanjutnya menentukan jumlah site untuk perencanaan perluasan jaringan LTE yang akan dilakukan.
Tabel 4. Network Throughput

\begin{tabular}{|l|l|l|l|l|}
\hline \multirow{2}{*}{ Parameter } & \multicolumn{2}{|l|}{ LTE (FDD) } & \multicolumn{2}{l|}{$\begin{array}{l}\text { LTE-A } \\
\text { (Carrier Aggregation) }\end{array}$} \\
\cline { 2 - 5 } & Uplink & Downlink & Uplink & Downlink \\
\hline $\begin{array}{l}\text { Total } \\
\text { Target }\end{array}$ & 35711 & & 16070 & \\
User & \multicolumn{4}{|l}{} \\
\hline $\begin{array}{l}\text { Single } \\
\text { User } \\
\text { Throughput } \\
\text { (Kbps) }\end{array}$ & 23,4535 & 245,4331 & 23,4535 & 245,4331 \\
\hline $\begin{array}{l}\text { Network } \\
\text { Throughput } \\
\text { (IP) } \\
\text { (Kbps) }\end{array}$ & 837547,6 & 8764659,9 & 376898,63 & 3944109,2 \\
\hline $\begin{array}{l}\text { Network } \\
\text { Throughput } \\
\text { (IP) } \\
\text { (Mbps) }\end{array}$ & 837,55 & 8764,66 & 3768,99 & 3944,11 \\
\hline
\end{tabular}

Tabel 5. MAC Layer Throughput

\begin{tabular}{|l|l|l|l|}
\hline \multicolumn{2}{|c|}{ LTE (FDD) } & \multicolumn{2}{l|}{$\begin{array}{l}\text { LTE-A } \\
\text { (Carrier Aggregation) }\end{array}$} \\
\hline DL & UL & DL & UL \\
Network & Network & Network & Network \\
Throughput & Throuhput & Throughput & $\begin{array}{l}\text { Throuhput } \\
\text { (Mbps) }\end{array}$ \\
(Mbps & (Mbps & (Mbps) \\
\hline 8939.8816 & 854.2918 & 4022.9592 & 384.4325 \\
\hline
\end{tabular}

Berdasarkan Tabel 12 ditunjukan jumlah site yang diperlukan untuk dilakukan perluasan coverage area LTE di daerah kabupaten Garut yang dibagi berdasarkan kecamatan. Jumlah keseluruhan site yang diperoleh berdasarkan perhitungan coverage untuk LTE FDD adalah sebanyak 73 site, sedangkan untuk LTE-A sebanyak 69 site.

\subsection{Trade Off}

Berdasarkan perhitungan perencanaan perluasan berdasarkan capacity dan coverage yang telah dilakukan didapatkan: $\begin{aligned} & \text { MAPL Capacity }=141.2016467 \mathrm{~dB} \\ & \text { MAPL Coverage }=142.6837993 \mathrm{~dB}\end{aligned}$

Untuk trade off yang diizinkan adalah rentang 0-5 dB karena selisih antara MAPL capacity dan MAPL coverage yang telah dihitung $<5 \mathrm{~dB}$ maka perhitungan jumlah site yang telah dilakukan dapat digunakan. Adapun Jumlah site yang digunakan untuk simulasi diambil jumlah site yang paling banyak, hal ini karena untuk mendapatkan kualitas sinyal yang baik. Sehingga untuk LTE (FDD) sebanyak 88 site dan LTE-A 69 site. 
Tabel 6. Distribusi SINR dan Kapasitas Per Site 1800 $\mathrm{MHz}$

\begin{tabular}{|c|c|c|c|c|c|c|}
\hline $\begin{array}{l}\text { Mod- } \\
\text { dulation }\end{array}$ & $\begin{array}{l}\text { Code } \\
\text { bit }\end{array}$ & $\begin{array}{l}\text { Code } \\
\text { rate }\end{array}$ & $\begin{array}{l}\begin{array}{l}\text { SINR } \\
(\mathrm{dB})\end{array} \\
\end{array}$ & $\begin{array}{l}\text { SINR } \\
(\mathrm{Pn})\end{array}$ & $\begin{array}{l}\text { DL Cell } \\
\text { (Mbps) }\end{array}$ & $\begin{array}{l}\text { UL Cell } \\
\text { (Mbps) }\end{array}$ \\
\hline $\begin{array}{l}\text { QPSK } \\
1 / 3\end{array}$ & 2 & 0,3 & $\begin{array}{l}-1,5 \\
-0,3\end{array}$ & 0,28 & 4,032 & 2,4192 \\
\hline $\begin{array}{l}\text { QPSK } \\
1 / 2\end{array}$ & 2 & 0,5 & $\begin{array}{l}0,3- \\
2\end{array}$ & 0,25 & 6 & 3,6 \\
\hline $\begin{array}{l}\text { QPSK } \\
2 / 3\end{array}$ & 2 & 0,67 & $\begin{array}{l}2- \\
4,5\end{array}$ & 0,17 & 5,4672 & 3,2803 \\
\hline $\begin{array}{l}16 \\
\text { QAM } \\
1 / 2\end{array}$ & 4 & 0,5 & $\begin{array}{l}4,5- \\
6\end{array}$ & 0,13 & 6,24 & 3,744 \\
\hline $\begin{array}{l}16 \\
\text { QAM } \\
2 / 3\end{array}$ & 4 & 0,67 & $\begin{array}{l}6- \\
8,5\end{array}$ & 0,1 & 6,432 & 3,8592 \\
\hline $\begin{array}{l}16 \\
\text { QAM } \\
4 / 5\end{array}$ & 4 & 0,8 & $\begin{array}{l}8,5- \\
10,8\end{array}$ & 0,05 & 3,84 & 2,304 \\
\hline $\begin{array}{l}64 \\
\text { QAM } \\
1 / 2\end{array}$ & 6 & 0,5 & $\begin{array}{l}10,8- \\
12,5\end{array}$ & 0,01 & 0,72 & 0,423 \\
\hline $\begin{array}{l}64 \\
\text { QAM } \\
2 / 3\end{array}$ & 6 & 0,67 & $\begin{array}{l}12,5 \\
- \\
13,5\end{array}$ & 0,01 & 0,9648 & 0,5789 \\
\hline \multicolumn{5}{|c|}{ Cell Average Throughput $=\Sigma P_{n} \times R_{n}$} & $\begin{array}{l}33,696 \\
101087\end{array}$ & $\begin{array}{l}20,2176 \\
606527\end{array}$ \\
\hline
\end{tabular}

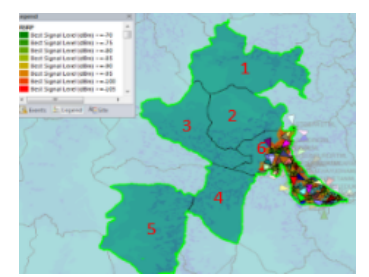

(a) RSRP

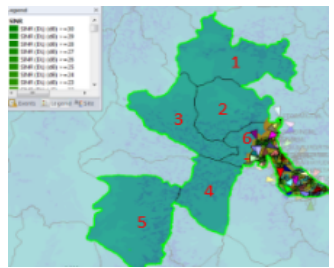

(b) SINR

\section{Gambar 3. Kondisi Awal LTE Parameter (a) RSRP dan (b) SINR}

\section{Hasil dan Pembahasan}

\subsection{Simulasi Kondisi Awal}

Daerah yang dilakukan perluasan berjumlah 6 kecamatan, yaitu: kecamatan Leles (1), kecamatan Tarogong Kaler (2), kecamatan Samarang (3), kecamatan Bayongbong (4), kecamatan Cisurupan (5), dan kecamatan Tarogong Kidul (6).

Berdasarkan Gambar 3 ditunjukan bahwa di daerah tersebut masih terdapat blank spot di beberapa kecamatan yang ditandai dengan nomor 1,2,3,4,5, dan 6 . Nilai RSRP rata-rata $-90.37 \mathrm{dBm}$ dan nilai SINR rata-rata $10.88 \mathrm{~dB}$. Kemudian persentase RSRP $>-100$ $\mathrm{dBm}$ yaitu $75,067 \%$ dan persentase SINR $>-5 \mathrm{~dB}$ yaitu $73.416 \%$. Nilai ini belum memenuhi memenuhi standar
Tabel 7. Distribusi SINR dan Kapasitas Per Site 850 $\mathrm{MHz}$

\begin{tabular}{|c|c|c|c|c|c|c|}
\hline $\begin{array}{l}\text { Mod- } \\
\text { dulation }\end{array}$ & $\begin{array}{l}\text { Code } \\
\text { bit }\end{array}$ & $\begin{array}{l}\text { Code } \\
\text { rate }\end{array}$ & $\begin{array}{l}\begin{array}{l}\text { SINR } \\
(\mathrm{dB})\end{array} \\
\end{array}$ & $\begin{array}{l}\text { SINR } \\
(\mathrm{Pn})\end{array}$ & $\begin{array}{l}\text { DL Cell } \\
\text { (Mbps) }\end{array}$ & $\begin{array}{l}\text { UL Cell } \\
\text { (Mbps) }\end{array}$ \\
\hline $\begin{array}{l}\text { QPSK } \\
1 / 3\end{array}$ & 2 & 0,3 & $\begin{array}{l}-1,5 \\
- \\
0,3\end{array}$ & 0,29 & 2,088 & 2,5056 \\
\hline $\begin{array}{l}\text { QPSK } \\
1 / 2\end{array}$ & 2 & 0,5 & $\begin{array}{l}0,3 \\
-2 \\
\end{array}$ & 0,27 & 3,24 & 3,888 \\
\hline $\begin{array}{l}\text { QPSK } \\
2 / 3\end{array}$ & 2 & 0,67 & $\begin{array}{l}2 \\
4,5\end{array}$ & 0,19 & 3,0552 & 3,6662 \\
\hline $\begin{array}{l}16 \\
\text { QAM } \\
1 / 2 \\
\end{array}$ & 4 & 0,5 & $\begin{array}{l}4,5 \\
-6\end{array}$ & 0,15 & 3,6 & 4,32 \\
\hline $\begin{array}{l}16 \\
\text { QAM } \\
2 / 3\end{array}$ & 4 & 0,67 & $\begin{array}{l}6- \\
8,5\end{array}$ & 0,14 & 4,5024 & 5,4029 \\
\hline $\begin{array}{l}16 \\
\text { QAM } \\
4 / 5\end{array}$ & 4 & 0,8 & $\begin{array}{l}8,5 \\
- \\
10,8\end{array}$ & 0,09 & 3,456 & 4,1472 \\
\hline $\begin{array}{l}64 \\
\text { QAM } \\
1 / 2 \\
\end{array}$ & 6 & 0,5 & $\begin{array}{l}10,8 \\
- \\
12,5 \\
\end{array}$ & 0,06 & 2,16 & 2,592 \\
\hline $\begin{array}{l}64 \\
\text { QAM } \\
2 / 3 \\
\end{array}$ & 6 & 0,67 & $\begin{array}{l}12,5 \\
- \\
13,5 \\
\end{array}$ & 0,05 & 2,412 & 2,8944 \\
\hline \multicolumn{5}{|c|}{ Cell Average Throughput $=\Sigma P_{n} \times R_{n}$} & \begin{tabular}{|l|}
24,5136 \\
73,5407
\end{tabular} & $\begin{array}{l}29,4163 \\
88,2489\end{array}$ \\
\hline
\end{tabular}

KPI untuk operator. Oleh sebab itu, perlu adanya perluasan coverage area LTE di daerah kabupaten Garut. Parameter uji selanjutnya adalah throughput dan user connected.

Berdasarkan Gambar 4 hasil simulasi throughput kondisi jaringan pada kondisi awal rata-rata throughput per-user sebesar 17,580 Mbps dan nilai persentase user yang gagal terkoneksi adalah 92,8 \%, sedangkan persentase user yang berhasil terkoneksi (user connected) adalah $7,2 \%$.

\subsection{Simulasi Setelah Perluasan}

\subsubsection{Simulasi LTE (FDD)}

Berdasarkan hasil perhitungan sebelumnya jumlah site pada perencanaan perluasan coverage area didapatkan 88 site untuk LTE (FDD).

Pada Gambar 5 ditunjukan bahwa telah terjadi perluasan coverage area pada beberapa kecamatan di daerah tersebut. Kuat level daya atau RSRP rata-ata setelah dilakukan perluasan yaitu $-65,91 \mathrm{dBm}$. Sedangkan kualitas sinyal atau SINR rata-rata setelah dilakukan perluasan yaitu 18,02 dB. Kemudian persentase RSRP $>-100 \mathrm{dBm}$ yaitu $95,1 \%$ dan persentase SINR $>5 \mathrm{~dB}$ yaitu $96,4 \%$. Nilai ini telah memenuhi standar KPI untuk operator.

Pada Gambar 6 ditunjukan bahwa hasil simulasi 
Tabel 8. Distribusi SINR dan Kapasitas Per Site 1800-850 MHz

\begin{tabular}{|c|c|c|c|c|c|c|}
\hline $\begin{array}{l}\text { Mod- } \\
\text { dulation }\end{array}$ & $\begin{array}{l}\text { Code } \\
\text { bit }\end{array}$ & $\begin{array}{l}\text { Code } \\
\text { rate }\end{array}$ & $\begin{array}{l}\text { SINR } \\
(\mathrm{dB})\end{array}$ & $\begin{array}{l}\text { SINR } \\
(\mathrm{Pn})\end{array}$ & $\begin{array}{l}\text { DL Cell } \\
(\mathrm{Mbps})\end{array}$ & $\begin{array}{l}\text { UL Cell } \\
\text { (Mbps) }\end{array}$ \\
\hline $\begin{array}{l}\text { QPSK } \\
1 / 3\end{array}$ & 2 & 0,3 & $\begin{array}{l}-1,5 \\
- \\
0,3\end{array}$ & 0,31 & 6,696 & 4,0176 \\
\hline $\begin{array}{l}\text { QPSK } \\
1 / 2\end{array}$ & 2 & 0,5 & $\begin{array}{l}0,3 \\
-2\end{array}$ & 0,39 & 14,04 & 8,424 \\
\hline $\begin{array}{l}\text { QPSK } \\
2 / 3\end{array}$ & 2 & 0,67 & $\begin{array}{l}2- \\
4,5\end{array}$ & 0,2 & 9,648 & 5,7888 \\
\hline $\begin{array}{l}16 \\
\text { QAM } \\
1 / 2\end{array}$ & 4 & 0,5 & $\begin{array}{l}4,5 \\
-6\end{array}$ & 0,17 & 12,24 & 7,344 \\
\hline $\begin{array}{l}16 \\
\text { QAM } \\
2 / 3 \\
\end{array}$ & 4 & 0,67 & $\begin{array}{l}6 \quad- \\
8,5\end{array}$ & 0,16 & 15,4368 & 9,2621 \\
\hline $\begin{array}{l}16 \\
\text { QAM } \\
4 / 5\end{array}$ & 4 & 0,8 & $\begin{array}{l}8,5 \\
- \\
10,8\end{array}$ & 0,09 & 10,368 & 6,2208 \\
\hline $\begin{array}{l}64 \\
\text { QAM } \\
1 / 2\end{array}$ & 6 & 0,5 & $\begin{array}{l}10,8 \\
- \\
12,5\end{array}$ & 0,08 & 8,64 & 5,184 \\
\hline $\begin{array}{l}64 \\
\text { QAM } \\
2 / 3\end{array}$ & 6 & 0,67 & $\begin{array}{l}12,5 \\
- \\
13,5\end{array}$ & 0,07 & 10,1304 & 6,0782 \\
\hline \multicolumn{5}{|c|}{ Cell Average Throughput $=\Sigma P_{n} \times R_{n}$} & $\begin{array}{l}87,1992 \\
261507\end{array}$ & $\begin{array}{l}52,3195 \\
156058\end{array}$ \\
\hline
\end{tabular}

throughput LTE (FDD) didapatkan rata-rata throughput per-user sebesar 24,962 Mbps dan persentase throughput $>12$ Mbps yaitu 89,7\% . Nilai ini telah memenuhi standar KPI operator. Kemudian untuk persentase user yang gagal terkoneksi adalah $6,7 \%$, sedangkan persentase user yang berhasil terkoneksi adalah 93,3\%.

\subsubsection{Simulasi LTE-A (Carrier Aggregation) dan SFR}

Berdasarkan hasil perhitungan sebelumnya jumlah site pada perencanaan perluasan coverage area untuk LTE A (Carrier Aggregation) dan SFR didapatkan 69 site. Pada Gambar 7 ditunjukan bahwa RSRP rata-rata setelah dilakukan perluasan LTE-A (Carrier Aggregation) serta SFR $-48,88 \mathrm{dBm}$ dan SNR 22,5 dB. Kemudian persentase RSRP $>-100 \mathrm{dBm}$ adalah $98,4 \%$ dan persentase SINR $>5 \mathrm{~dB}$ adalah 96,59\%. Nilai ini telah memenuhi standar KPI untuk operator. Pada Gambar 8 didapatkan rata-rata throughput per-user sebesar 28,923 Mbps. Nilai tersebut lebih besar dan telah terjadi peningkatan jika dibandingkan dengan hasil simulasi LTE (FDD). Nilai ini juga telah memenuhi standar KPI. Kemudian persentase user yang gagal terkoneksi adalah 5,5\%, sedangkan persentase user yang berhasil terkoneksi adalah 94,5\%.
Tabel 9. Jumlah Site Berdasarkan Capacity

\begin{tabular}{|l|r|r|r|r|}
\hline \multirow{2}{*}{ Item } & \multicolumn{2}{|c|}{ LTE } & \multicolumn{2}{c|}{$\begin{array}{c}\text { LTE-A (Carrier } \\
\text { Aggregation) }\end{array}$} \\
\cline { 2 - 5 } & Uplink & Downlink & \multicolumn{1}{c|}{ Uplink } & Downlink \\
\hline $\begin{array}{l}\text { Coverage } \\
\left.\text { Area (km }{ }^{2}\right)\end{array}$ & \multicolumn{2}{|c|}{331,76} & \multicolumn{2}{c|}{331,76} \\
\hline User & \multicolumn{2}{|c|}{35711} & \multicolumn{2}{c|}{16070} \\
\hline SUT (Kbps) & 23,4535 & 245,4331 & 23,4535 & 245,4331 \\
\hline $\begin{array}{l}\text { Network } \\
\text { Troughput } \\
\text { (Mbps) }\end{array}$ & 854,2918 & 8939,8816 & 384,43 & 4022,96 \\
\hline $\begin{array}{l}\text { Cell Average } \\
\text { Throughput } \\
\text { (Mbps) }\end{array}$ & 20,2176 & 33,696 & 52,3195 & 87,1992 \\
\hline $\begin{array}{l}\text { Site } \\
\text { Capacity } \\
\text { (Mbps) }\end{array}$ & 60,6528 & 101,088 & 156,9585 & 261,5976 \\
\hline $\begin{array}{l}\text { Number of } \\
\text { Site }\end{array}$ & 14 & 88 & & 15 \\
\hline $\begin{array}{l}\text { Cell } \\
\text { Coverage } \\
\text { (km }{ }^{2} \text { ) }\end{array}$ & 23,5542 & 3,7513 & 135,4530 & 21,5730 \\
\hline $\begin{array}{l}\text { Cell Radius } \\
\text { km }{ }^{2} \text { ) }\end{array}$ & 3,4754 & 1,3870 & 8,3344 & 3,3261 \\
\hline
\end{tabular}

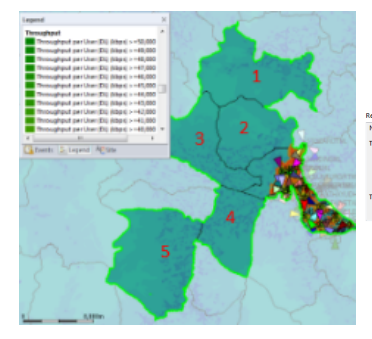

(a) Throughput

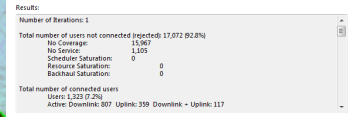

(b) User Connected

\section{Gambar 4. Kondisi Awal LTE Parameter (a)Throughput dan (b) User Connected}

\subsection{Analisis Hasil Simulasi}

Berdasarkan hasil simulasi yang telah dilakukan berikut Tabel 13 menunjukan hasil akhir perluasan coverage area LTE di kabupaten Garut.

Berdasarkan hasil simulasi perluasan coverage area yang telah dilakukan, sebagai rekomendasi bagi operator, yang lebih baik untuk di implementasikan di daerah Garut adalah perluasan coverage area menggunakan LTE-A (Carrier Aggregation) dan SFR. Hal ini dikarenakan pertimbangan efisiensi biaya untuk jumlah site yang dibangun lebih sedikit yaitu sebanyak 69 site, serta performansi jaringan yang lebih baik dari sisi coverage dengan RSRP rata-rata $-48,88 \mathrm{dBm}$, serta kualitas jaringan yang lebih baik dengan SINR rata-rata 22,5 dB, throughput 28,923 Mbps, dan user connected 94,5\%. Perluasan coverage area di daerah Garut menggunakan LTE-A (Carrier Aggregation) dan SFR menjadi solusi efektif dalam memanfaatkan bandwidth 5 $\mathrm{MHz}$ pada band $5(850 \mathrm{MHz})$, dan bandwidth $10 \mathrm{MHz}$ pada band 3 (1800 MHz), sehingga dapat mengefisiensi spektrum frekuensi yang terbatas. 


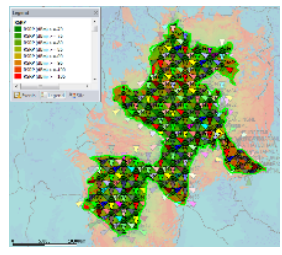

(a) RSPR

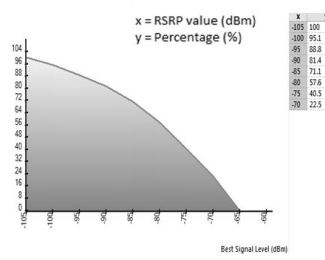

(c) CDF RSPR

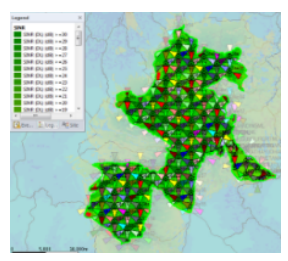

(b) SINR

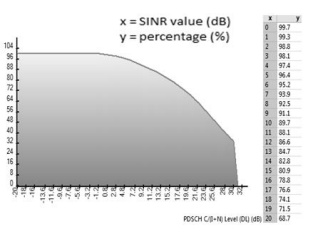

(d) CDF SINR
Gambar 5. Hasil Simulasi Perluasan LTE (FDD) Parameter RSRP dan SINR

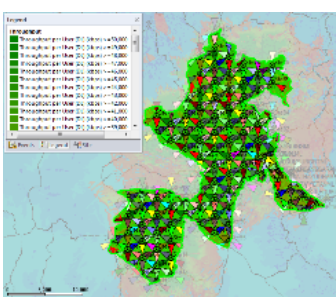

(a) Throughput

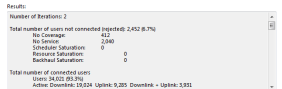

(b) User Connected
Gambar 6. Hasil Simulasi Perluasan LTE (FDD) Parameter Throughput dan User Connected

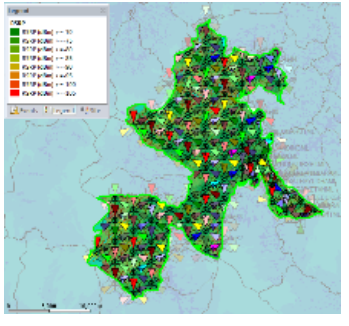

(a) RSPR

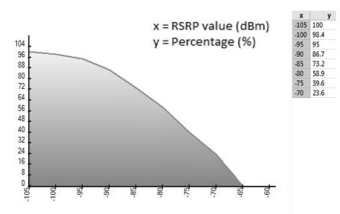

(c) CDF RSPR

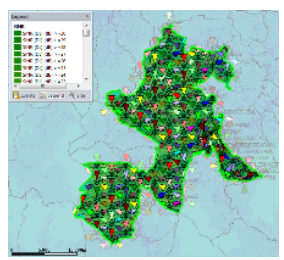

(b) SINR

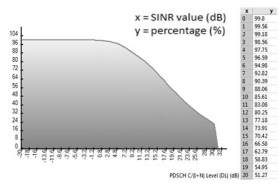

(d) CDF SINR
Gambar 7. Hasil Simulasi Perluasan LTE (FDD) Parameter RSRP dan SINR
Tabel 10. Maximum Allowable Pathloss (MAPL) [6]

\begin{tabular}{|c|c|c|c|c|c|}
\hline \multicolumn{6}{|c|}{ Link budget for MAPL \& Cell radius calculation } \\
\hline \multirow{2}{*}{ Morphology } & Sub & rban & Sub & rban & \multirow{4}{*}{ Formula } \\
\hline & UL & DL & UL & DL & \\
\hline $\begin{array}{c}\text { Duplex } \\
\text { mode }\end{array}$ & \multicolumn{4}{|c|}{ FDD } & \\
\hline $\begin{array}{l}\text { Carrier } \\
\text { frequency } \\
(\mathrm{MHz})\end{array}$ & \multicolumn{4}{|c|}{$1800 ; 850$} & \\
\hline Transmitter & UE & ENodeB & UE & eNodeB & \\
\hline $\begin{array}{l}\text { Max total } \\
\text { Tx power } \\
(\mathrm{dBm})\end{array}$ & 23 & 43 & 23 & 46 & A \\
\hline $\begin{array}{c}\text { RB to } \\
\text { distributed } \\
\text { power }\end{array}$ & 3 & 100 & 3 & 100 & C \\
\hline $\begin{array}{c}\text { Subcarriers } \\
\text { to } \\
\text { distributed } \\
\text { power }\end{array}$ & 36 & 1200 & 36 & 1200 & $\mathrm{D}=12 * \mathrm{C}$ \\
\hline $\begin{array}{c}\text { Subcarrier } \\
\text { power } \\
(\mathrm{dBm})\end{array}$ & 7,437 & 12,208 & 7,437 & 12,208 & $\mathrm{E}=\mathrm{A}-10 * \log (\mathrm{D})$ \\
\hline $\begin{array}{l}\text { Tx antena } \\
\text { gain }(\mathrm{dBi})\end{array}$ & 0 & 17 & 0 & 17 & G \\
\hline $\begin{array}{l}\text { Tx cable } \\
\text { loss }(\mathrm{dB})\end{array}$ & 0 & 0.5 & 0 & 0.5 & $\mathrm{H}$ \\
\hline $\begin{array}{l}\text { EIRP per } \\
\text { subcarrier } \\
(\mathrm{dBm})\end{array}$ & 7,437 & 28,708 & 7,437 & 28,708 & $\mathrm{~J}=\mathrm{E}+\mathrm{G}-\mathrm{H}$ \\
\hline Receiver & ENodeB & $\mathrm{UE}$ & eNodeB & UE & \\
\hline SINR (dB) & -6 & -5 & -6 & -5 & $\mathrm{~K}$ \\
\hline $\begin{array}{c}\text { Rx noise } \\
\text { figure }(\mathrm{dB})\end{array}$ & 2 & 3 & 2 & 3 & $\mathrm{~L}$ \\
\hline $\begin{array}{l}\text { Receiver } \\
\text { sensitivity } \\
(\mathrm{dBm})\end{array}$ & 136,239 & $\begin{array}{c}- \\
134,239\end{array}$ & 136,239 & 134,239 & $\begin{array}{c}\mathrm{M}=\mathrm{K}+\mathrm{L}- \\
174+10^{*} \log (15000)\end{array}$ \\
\hline $\begin{array}{l}\text { Rx antena } \\
\text { gain }(\mathrm{dBi})\end{array}$ & 17 & 0 & 17 & 0 & $\mathrm{~N}$ \\
\hline $\begin{array}{l}\text { Rx body } \\
\text { loss }(\mathrm{dB})\end{array}$ & 2 & 2 & 2 & 2 & $\mathrm{P}$ \\
\hline $\begin{array}{c}\text { Interference } \\
\text { margin }\end{array}$ & 2 & 3,13 & 2 & 3,13 & Q \\
\hline $\begin{array}{l}\text { Min signal } \\
\text { reception } \\
\text { strength } \\
(\mathrm{dBm})\end{array}$ & $-132,23$ & $-129,10$ & $-132,23$ & $-129,10$ & $\mathrm{R}=\mathrm{M}+\mathrm{P}+\mathrm{Q}$ \\
\hline & & thloss \& S & dow fadin & margin & \\
\hline $\begin{array}{c}\text { Penetration } \\
\text { loss }(\mathrm{dB})\end{array}$ & 10 & 10 & 11 & 11 & S \\
\hline $\begin{array}{c}\text { Shadow } \\
\text { fading } \\
\text { margin }(\mathrm{dB})\end{array}$ & 4 & 4 & 5 & 5 & $\mathrm{~T}$ \\
\hline $\begin{array}{c}\text { Max } \\
\text { allowed } \\
\text { path loss } \\
\text { (dB) }\end{array}$ & 142,67 & 143,81 & 132,67 & 133,81 & $\mathrm{U}=\mathrm{J}+\mathrm{N}-\mathrm{R}-\mathrm{S}-\mathrm{T}$ \\
\hline
\end{tabular}

\section{Penutup}

\subsection{Kesimpulan}

Adapun kesimpulan dari penelitian ini antara lain:

1. Kebutuhan jumlah site untuk perluasan coverage area LTE di daerah kabupaten Garut yaitu 88 site untuk perluasan menggunakan LTE (FDD) dan 69 site untuk perluasan menggunakan LTE-A (Carrier Aggregation) yang dikombinasikan dengan SFR.

2. Hasil simulasi perluasan coverage area di daerah Garut menggunakan LTE (FDD), didapatkan nilai parameter RSRP rata-rata $-65,91 \mathrm{dBm}$, SINR rata-rata $18,02 \mathrm{~dB}$, throughput $24,962 \mathrm{Mbps}$, dan user connected $93,3 \%$. Sedangkan hasil simulasi perluasan coverage area di daerah Garut menggunakan LTE-A (Carrier Aggregation) yang dikombinasikan dengan SFR, didapatkan nilai parameter RSRP rata-rata $-48,88 \mathrm{dBm}$, SINR rata-rata 22,5 $\mathrm{dB}$, throughput 28,923 $\mathrm{Mbps}$, dan 
Tabel 11. Radius Cell

\begin{tabular}{|c|c|c|c|c|}
\hline $\begin{array}{c}\text { Propagation } \\
\text { model }\end{array}$ & \multicolumn{2}{|c|}{ Cost231-hata } & \multicolumn{2}{c|}{ Okumurra Hatta } \\
\hline $\begin{array}{c}\text { eNodeB antenna } \\
\text { height (m) }\end{array}$ & 30 & 30 & 30 & 30 \\
\hline $\begin{array}{c}\text { UE antenna } \\
\text { height (m) }\end{array}$ & 1,5 & 1,5 & 1,5 & 1,5 \\
\hline $\begin{array}{c}\text { Frequency } \\
(\mathrm{Mhz})\end{array}$ & 1800 & 1800 & 850 & 850 \\
\hline $\mathrm{a}(\mathrm{Hr})$ & 0,04297 & 0,04297 & 0,01365 & 0,01365 \\
\hline Cell radius $(\mathrm{km})$ & 1,5281132 & 1,6464646 & 1,571968 & 1,693716323 \\
\hline
\end{tabular}

Tabel 12. Jumlah Site Berdasarkan Perencanaan Coverage

\begin{tabular}{|l|c|c|c|c|c|}
\hline \multirow{2}{*}{ District } & \multirow{2}{*}{$\begin{array}{c}\text { Large } \\
\text { District } \\
\left(\mathrm{km}^{2}\right)\end{array}$} & \multicolumn{2}{|c|}{ LTE (FDD) } & \multicolumn{2}{|c|}{$\begin{array}{c}\text { LTE-A (Carrier } \\
\text { Aggregation) }\end{array}$} \\
\cline { 3 - 6 } & & $\begin{array}{c}\text { Cell } \\
\text { Coverage } \\
\left(\mathrm{km}^{2}\right)\end{array}$ & $\begin{array}{c}\text { Total } \\
\text { Site }\end{array}$ & $\begin{array}{c}\text { Cell } \\
\text { Coverage } \\
\left(\mathrm{km}^{2}\right)\end{array}$ & $\begin{array}{c}\text { Total } \\
\text { Site }\end{array}$ \\
\hline Leles & 73,51 & 4,55 & 16 & 4,82 & 15 \\
\hline Bayongbong & 47,63 & 4,55 & 10 & 4,82 & 10 \\
\hline Cisurupan & 80,88 & 4,55 & 18 & 4,82 & 17 \\
\hline $\begin{array}{l}\text { Tarogong } \\
\text { Kidul }\end{array}$ & 19,46 & 4,55 & 4 & 4,82 & 4 \\
\hline $\begin{array}{l}\text { Tarogong } \\
\text { Kaler }\end{array}$ & 50,57 & 4,55 & 11 & 4,82 & 10 \\
\hline Samarang & 59,71 & 4,55 & 13 & 4,82 & 12 \\
\hline Jumlah & 331,76 & & 73 & & 69 \\
\hline
\end{tabular}

user connected 94,5\%. Nilai-nilai parameter tersebut telah memenuhi standar KPI operator.

3. Hasil simulasi perluasan coverage area di daerah Garut, didapatkan peningkatan coverage area sebesar 331,76 km2 (92,291429\%) menggunakan LTE (FDD) maupun LTE-A (Carrier Aggregation) yang dikombinasikan dengan SFR dibandingkan dengan kondisi awal sebesar 27,71 km2 $(7,70857 \%)$.

4. Penggunaan fitur carrier aggregation pada band 3 (1800 MHz) dengan bandwidth $10 \mathrm{MHz}$ dan band 5 (850 MHz) dengan bandwidth $5 \mathrm{MHz}$ baik untuk meningkatkan nilai RSRP, SINR, throughput, dan user connected. Sedangkan penggunaan fitur SFR,
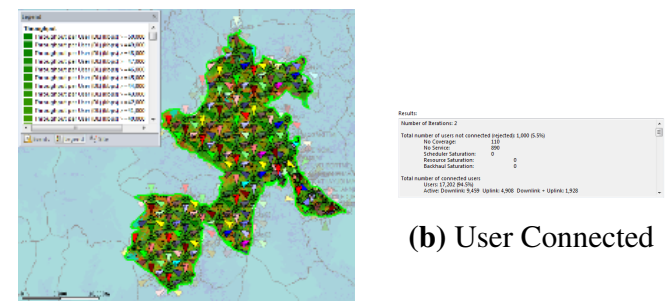

(b) User Connected

(a) Throughput

Gambar 8. Hasil simulasi perluasan LTE-A (Carrier Aggregation) serta SFR parameter (a) Throughput dan (b) User Connected
Tabel 13. Hasil Akhir Simulasi Perluasan Coverage LTE di Kabupaten Garut

\begin{tabular}{|c|c|c|c|c|}
\hline No. & Parameter & $\begin{array}{l}\text { Kondisi } \\
\text { LTE } \\
\text { Awal }\end{array}$ & $\begin{array}{c}\text { LTE } \\
\text { (FDD) }\end{array}$ & $\begin{array}{c}\text { LTE-A } \\
\text { (Carrier } \\
\text { Aggregation) } \\
\text { dan SFR } \\
\end{array}$ \\
\hline 1 & RSRP (dBm) & $-90,37$ & $-65,91$ & $-48,88$ \\
\hline 2 & SINR (dB) & 10,88 & 18,02 & 22,5 \\
\hline 3 & $\begin{array}{l}\text { Throughput } \\
\text { (Mbps) }\end{array}$ & 17,580 & 24,962 & 28,923 \\
\hline 4 & $\begin{array}{l}\text { User Connected } \\
(\%)\end{array}$ & $7,2 \%$ & $93,3 \%$ & $94,5 \%$ \\
\hline 5 & $\begin{array}{l}\text { Jumlah Site } \\
\text { (site) }\end{array}$ & 15 & 88 & 69 \\
\hline 6 & $\begin{array}{l}\text { Luas Cakupan } \\
\left(\mathrm{km}^{2}\right)\end{array}$ & 27,71 & 331,76 & 331,76 \\
\hline 7 & Persentase $(\%)$ & 7,70857 & 92,291429 & 92,291429 \\
\hline 8 & $\begin{array}{l}\text { Jumlah Site } \\
\text { Kumulatif (site) } \\
\text { (Kondisi Awal } \\
+ \text { Perluasan) }\end{array}$ & 15 & 103 & 84 \\
\hline 9 & $\begin{array}{l}\text { Luas Cakupan } \\
\text { Kumulatif } \\
\left(\mathrm{km}^{2}\right) \\
\text { (Kondisi Awal } \\
+ \text { Perluasan) }\end{array}$ & 27,71 & 359,47 & 359,47 \\
\hline 10 & $\begin{array}{l}\text { Persentase Luas } \\
\text { Cakupan } \\
\text { Kumulatif (\%) } \\
\text { (Kondisi Awal } \\
+ \text { Perluasan) }\end{array}$ & 7,70857 & 100 & 100 \\
\hline
\end{tabular}

baik untuk meminimalisir interferensi di cell center maupun di cell edge sehingga kualitas jaringan tetap terjaga.

5. Perluasan coverage area LTE yang lebih baik untuk diimplementasikan di daerah Garut adalah perluasan coverage area menggunakan LTE-A (Carrier Aggregation) dan SFR. Hal ini dikarenakan pertimbangan penghematan biaya untuk jumlah site yang dibangun lebih sedikit dan performansi jaringan yang lebih baik.

\section{Daftar Pustaka}

[1] N. Fathimah, A. Fahmi, and U. K. Usman, "Analisis perencanaan perluasan coverage area pada jaringan lte di area kabupaten bandung barat," eProceedings of Engineering, vol. 5, no. 2, 2018.

[2] D. W. Saputra, U. K. Usman, and L. Meylani, "Analisis perencanaan LTE-advanced dengan metoda carrier aggregation inter-band non-contiguous dan intra-band non-contiguous di kota bandar lampung," eProceedings of Engineering, vol. 2, no. 2, 2015. 
[3] U. K. Usman, G. Prihatmoko, D. K. Hendraningrat, and S. D. Purwanto, "Fundamental teknologi seluler lte,” Bandung, Indonesia: Rekayasa Sains, 2012.

[4] H. Hendra Lesmana Sakti, "Perencanaan jaringan lte-advanced dengan metode carrier aggregation (ca) intra-band contiguous di kota bandung," Ph.D. dissertation, UIN Sunan Gunung Djati Bandung, 2016.

[5] “LTE cell planning," Huawei Technologies, 2010.

[6] “LTE cell planning,” Huawei Technologies, 2013. 